\title{
Redox-controlled mobility of arsenic and cadmium in paddy soil amended with organic matter, sulfate, and iron oxide
}

\author{
ChaOlei YuAN, FANGBAi Li*
}

Guangdong Key Laboratory of Integrated Agro-

environmental Pollution Control and Management,

Guangdong Institute of Eco-environmental Science \&

Technology, China (*correspondence: cefbli@soil.gd.cn)

Organic matter, sulfate, and iron oxide have been commonly used for the remediation of paddy soils contaminated by arsenic (As) and/or cadmium (Cd). These amendments can influence soil redox processes and regulates the mobility of the metal contaminants. However, the underlying chemical and microbial mechanisms are not fully understood at environmentally realistic concentrations.

A paddy soil that contained $33 \mathrm{mg} \mathrm{kg}^{-1}$ total As and 0.36 $\mathrm{mg} \mathrm{kg}{ }^{-1}$ total $\mathrm{Cd}$ was amended with rice straw, gypsum, or hematite; the soil was then incubated in microcosms after submergence and redrying [1]. Rice straw significantly promoted the microbial reduction of $\mathrm{Fe}(\mathrm{III})$ and $\mathrm{As}(\mathrm{V})$ as well as the increase in soil $\mathrm{pH}$ after submergence. This resulted in the rapid mobilization of As and immobilization of Cd. Nevertheless, after 8 weeks, the phosphate-extractable As concentration in the straw-amended soil was lower than that in the unamended control soil, possibly due to the precipitation of As(III) in secondary iron minerals. After 5 weeks of re-drying, phosphate-extractable As concentration was higher and dissolved $\mathrm{Cd}$ concentration was lower in the straw-amended soil than the control soil, because $\mathrm{pH}$ of the straw-amended soil was higher than that of the control soil.

Compared to rice straw, gypsum and hematite had smaller effects on the mobility of $\mathrm{As}$ and $\mathrm{Cd}$. Added hematite decreased Cd solubility by approximately $30 \%$ compared to the control during the wet and dry periods. Added gypsum and hematite, which inhibited mirobial $\mathrm{Fe}(\mathrm{III})$ and $\mathrm{As}(\mathrm{V})$ reduction, reduced As mobility by $8-60 \%$.

Molecular biological analyses further showed that rice straw, rather gypsum or hematite, greatly stimulated the growth of iron-reducing bacteria. Moreover, soil As concentrations were related to the abundance and community composition of the $\operatorname{arr} A$ gene [mediating dissimilatory $\mathrm{As}(\mathrm{V})$ reduction], rather than the $\operatorname{ars} C$ gene [mediating cytoplasmic $\mathrm{As}(\mathrm{V})$ reduction] or the aioA gene [mediating $\mathrm{As}(\mathrm{III})$ oxidation].

[1] Yuan et al. (2019), J. Hazard. Mater. 378, 120672

https://doi.org/10.1016/j.jhazmat.2019.05.065 